\title{
A Research on the Relationship between Leadership Orientations and the Innovativeness of Owner-Managers in Turkish Businesses
}

\author{
Evren Ayranci \\ Faculty of Economics and Administrative Sciences, Istanbul Aydin University \\ Besyol Mah. Inonu Cad. No: 40, Sefakoy-Kucukcekmece / Istanbul, Turkey \\ Tel: +90-532-405-4094_E-mail: xonox@mynet.com
}

Received: February 1, 2011 Accepted: February 19, 2011 doi:10.5430/jms.v2n1p48

\begin{abstract}
Relevant literature notes that leadership in business contexts inspires innovativeness. This study considers this insight as a starting point but moves beyond the existing literature by focusing only on leaders to understand how leadership inspires a leader's own innovativeness. The author chose the people who own and manage a business (owner-managers) and used the perceptions of workers in businesses to evaluate the existence of leadership as well as leadership orientations of owner-managers. The key objectives of this study - namely, evaluating how perceived leadership and leadership orientations of owner-managers affect their own innovativeness - reveal remarkable results. There are two leadership orientations, one focusing on the work and the other that focuses on people. There are many factors related to owner-manager innovativeness. The perceived leadership of owner-managers moderately affects their innovativeness in a positive direction. The factors related to people-oriented leadership can also affect their innovativeness positively at a moderate level.
\end{abstract}

Keywords: Leadership, Innovativeness, Owner, Manager, Turkey

\section{Introduction}

The concepts of leadership and innovation have been analyzed in the context of business for many years, becoming the subject of many studies. According to these studies, some aspects of leadership and innovation have very strong relationships. These claims usually depend on the fact that people- and transformation-oriented leaders are more innovative, which can also foster innovativeness in a business context (Adair, 2007; Burpitt \& Bigoness, 1997; Eisenbeiss, Knippenberg, \& Boerner, 2008; Jung, Chow, \& Wu, 2003; Klemm, 2001; Krause, Gebert, \& Kearney, 2007).

The existing literature, however, exhibits two important gaps. First of all, there are very few studies that analyze the leadership-innovation relationship in a Turkish business context (but see Gumusluoglu \& Ilsev, 2009; Mogulkoc, 2009). Though it is often claimed that leadership can be a tool to encourage innovation, there are few studies that analyze the leadership-innovativeness relationship in relation to leaders specifically. This study fills in these gaps and may be considered as a contribution to not only the literature on Turkey but also to the international literature as well.

The participants in this study were people who owned and managed their businesses (i.e., owner-managers). The leadership orientations, which emphasized either people or work, and the innovativeness of the owner-managers were assessed by multiple well-known instruments, which have already been used in the international literature. The purpose of the study was to understand whether and how the existence of leadership and leadership orientations of owner-managers could affect their innovativeness.

The present author acknowledged that owner-managers might not be leaders themselves. In other words, simply having the title of owner and manager did not necessarily imply the title of leader. Based on this premise, the workers in the businesses of the owner-managers were asked whether they saw these owner-managers as leaders. The workers were also required to fill out questionnaires related to the orientations of the owner-managers. As such, the workers of each participating business provided data about the leadership orientations of that business's owner-manager, allowing this study to consider perceived leadership orientations as well. Self-reporting was used for owner-manager innovativeness.

The results revealed that leadership orientations depended on four factors. Two of these factors involved the leader's focus on the work, whereas the other two involved the leader's focus on the people. The other concept, innovativeness, was composed of five factors, namely, idealism, flexibility, distinction, systematic approach and hunch. The overall result of the research was that the perceived leadership of owner-managers could positively affect their innovativeness. 
Another important point was that factors related to owner-manager people-oriented leadership could inspire their innovativeness, again in a positive way.

\section{Some Definitions of Innovativeness}

There are many different definitions of innovativeness, but generally the term can be thought of as the use of the capacity and the capability to act with a new understanding or the expression of the capacity to assess a subject in an unconventional way. According to certain definitions of innovativeness, this capacity or capability includes creativity as well, as addressed below.

Innovativeness may be thought of as a property of humans, an emotional process and even a lifestyle that is related to intelligence, efficiency, originality and unconventionality (Yavuzer, 1994). Such issues are mentioned across many different definitions of innovativeness throughout the literature. Guilford (1961) defines innovativeness as a learned ability and contends that the use of this ability mainly involves thinking in a style different from others. Torrance and Wu (1981) develop a more detailed definition. They claim that being innovative involves being sensitive to problems, imperfections, lost information and inconsistencies, perceiving difficulties, looking for solutions, making guesses, formulating new assumptions and analyzing the results of these assumptions. In newer studies, innovativeness is defined as producing flexible thoughts (Kiesswetter, 1983), the ability to produce authentic ideas in different conditions (Gibson \& Chandler, 1988), the ability to produce meaningful answers with one's own ideas and capabilities in order to solve problems (Wakefield, 1992), the cognitive process that emerges as a person's own capabilities (Diakidoy \& Kanari, 1999) and separation from other people's ways of thinking through the production of unconventional solutions using new axes of thoughts (Riza, 2000).

The literature contends that innovation is not a single-step concept; rather, it is a process. While some studies consider the innovation process in terms of the general steps that may be considered to solve different problems (Vecchio, 1988), other studies consider this process in relation to a business context (Chesbrough, 2004; Choi \& Valikangas, 2001; Herzog, 2008). The use of special techniques such as synectic techniques (Hodgetts, 1998), brainstorming, meditation and cognitive mapping (Luthans, 1995) are also favored in this process.

\section{The Relationship between Leadership and Innovativeness}

It is remarkable that leadership only has been a scientific subject since the beginning of the twentieth century. Scholars have developed various approaches to leadership, with the number of studies on the subject increasing sharply after the 1940s (Guney, 2000). These approaches and studies are not, however, the focus of this study, and hence, they are not explained in this section. Rather, it seems more pertinent to define leadership and focus on studies that consider the relationships between leadership and innovativeness.

There are many different definitions of leadership throughout the literature. According to one of these definitions, a leader is the person who determines the goals of his/her own group and who can direct the group in the most effective way to make these goals happen; as such, leadership is the art of enabling people to carry out their tasks willingly and voluntarily (Baysal \& Tekarslan, 2004).

The leader may also be the person who is followed by other people in a specific group with an intention to reach personal and/or group goals (Kocel, 2003). In this case, leadership can be considered the ability to gather a group of people around specific purposes and encourage them to achieve these purposes (Zel, 2001).

Some studies that define and include leadership also include innovation. Eigen and Siegel (1989) separate leadership from management by noting that managers perform the work in the "right" way, but leaders choose or determine what this right way should be. According to these two scholars, leaders may choose among existing alternatives; they may choose to consider one of these alternatives in a unique, unconventional way, or they may think of new alternatives that have never been considered before. Bennis (1989) has very similar framework and contends that managers do not usually show new approaches; rather, leaders deliver newness, show original behaviors, produce solutions that have never been used before and invent. In this case, these studies suggest that innovativeness can be a characteristic of leaders.

Besides the two studies mentioned above, there are also many studies that discuss the leadership-innovativeness relationship within an organizational context. A general result put forward by relatively older studies is that there are relationships between innovativeness and some specific leadership types (Hage \& Dewar, 1973; Maier, 1970). Newer studies from the 1990s and later provide many insights on these relationships. 
Current studies on leadership and personal or organizational innovativeness make the following contributions.

- Transformational leaders cause workers to feel freer. Because of this, workers start to exhibit more cooperation, become more willing to have initiative, develop new and original ideas and act more effectively as a team (Adair, 2007; Burpitt \& Bigoness, 1997; Eisenbeiss et al., 2008).

- Transformational leadership is very effective at encouraging organizational creativity and innovativeness (Gumusluoglu \& Ilsev, 2009; Hunt, Stelluto, \& Hooijberg, 2004; Junga et al., 2003).

- Leaders can encourage their workers to be more creative and innovative by using organizational culture (Herzog, 2008; Yukl, 2001) as well as support mechanisms such as material rewards (Baer, Oldham, \& Cummings, 2003; Gumusluoglu, 2009; Mumford \& Gustafson, 1988).

- Leaders can directly affect the work context and the rules of working in order to enhance organizational creativity and innovativeness (Amabile, 1998).

- Leaders can determine and shape the organizational vision, and with this vision, they can cause workers to focus on long-term innovative working processes by encouraging creativity among workers (Amabile, 1997).

- The leaders of the organizations in developed countries claim that their organizations must foster innovativeness, instead of merely reverting to the usual methods of cutting back costs and improving effectiveness, in order to compete with organizations in developing countries (Daft, 2008).

Current studies that focus on leadership and the innovativeness of leaders making the following contributions.

- The emotional intelligence of a leader may also be an important factor for that leader to be innovative and to promote creativity in the organization (Cengiz, Acuner, \&Baki, 2006; Zhou \& George, 2003).

- An effective leader should be creative, encourage the emergence and application of innovative ideas and be people-oriented (Rowitz, 2001).

- There exist various leadership capabilities, and for each capability, characteristics such as a propensity for innovation and social skills are essential (Crosby \& Bryson, 2005).

- The innovation should also be led. An innovation leader should have many characteristics, one of which is the ability to engage workers in the organization and to communicate enthusiastically (Deschamps, 2003).

\section{Research on the Relationship between Owner-Manager Leadership Orientations and Owner-Manager Innovativeness}

The studies noted in the prior section contend that there are relationships between leadership and innovativeness. Moreover, the prior section shows that the innovativeness of a leader becomes important if the leader is to transform the organization or focus on interpersonal relationships.

The author of this study considered the abovementioned studies in order to understand whether and how the leadership orientations of people who own and manage a business (i.e., owner-managers) are related to their innovativeness. The research did not focus on the transformational leadership characteristics unlike some of the studies mentioned in the previous section, and therefore, this type of leadership was not the focus of this research. Rather, the present study covered two dimensions of leadership: work-oriented and being people-oriented dimensions of leadership. Prior studies have discovered that leadership is a cause of innovativeness. The author expected this to be true for this study as well such that owner-manager leadership orientations would positively affect their innovativeness.

\subsection{Population, sample and data collection method}

The research considered the relationship between owner-manager leadership orientations and their innovativeness. There are many pitfalls in this approach. First of all, being an owner, manager and leader are three distinct properties. What's more, being a leader and being a specific type of leader are also quite different matters. It is also important to note that leadership is a social concept, and therefore, if a person is perceived as a leader, there may be vast distinctions between a leader's own perceptions about his/her leadership and the perceptions of others regarding the leader.

Because of these issues, the choice of who provides the data on leadership orientations is a vital question. Innovativeness is the expression of one's own capacity and ability, which makes it convenient to use self-reporting techniques. The author indeed used self-reporting for innovativeness and asked owner-managers to provide data on their own innovativeness. In addition to self-reporting, other people can be asked to assess the leadership of a specific person. The author considered this approach as well, ultimately deciding to use the perceptions of others regarding the leadership of owner-managers. As a result, this study employed two sets of data, namely, data collected from the owner-managers on 
their own innovativeness and data provided by workers in each business, which showed whether the owner-manager was seen as a leader, and if so, the leadership orientation.

Due to the difficulties of acquiring the required data from large businesses, the author decided to consider small- and medium-sized enterprises (SMEs). As compared with big businesses, it was easier to access the owners of SMEs and collect data from their workers. The owners of most SMEs were also managers due to the nature of these businesses. Time and budget issues led the author to collect data from the SMEs in an organized industrial zone, as these zones usually include many SMEs.

Based on the considerations mentioned in the prior paragraphs, the author defined the target population as owner-managers and workers at SMEs in the Istanbul Dudullu Organized Industrial Zone. This zone included 137 businesses with more than 500 people as of October 24, 2010 (Dudullu Organized Industrial Zone, 2010).

The data were collected by questionnaires. As there was no appropriate instrument in the existing literature, assessing the innovativeness of the owner-managers was challenging. The author used a blend of various individual and organizational innovativeness instruments with some rewording, including the "How Creative Are You?" scale (Raudsepp \& Hough, 1977), “The Innovativeness Scale" (Hurt, Joseph, \& Cook, 1977) and some items related to personal innovativeness from Agarwal and Prasad's (1998) study.

The questionnaires for workers began with the question "Do you perceive the person (people) who is (are) both the owner(s) and the manager(s) of your business as your leader(s) in this business context?" and continued with reworded items from Luthans's (1995) "Leadership Orientation Inventory" scale. The data collection process started on October 25, 2010, and ended on December 1, 2010.

There were 137 cases at the end of the data-gathering process, but the analyses were performed with only 83 cases due to missing or obsolete data. In addition, some cases were excluded due to the fact that some workers did not perceive their business owner-managers as leaders, and some businesses had distinct manager and owner positions.

\subsection{Reliabilities and statistical structures of the data}

Because the instruments in the questionnaires had never been used together in a Turkish business context, the author decided to perform exploratory factor analyses to elucidate the statistical structures of the acquired data. As the data were provided by two different groups (i.e., owner-managers and workers), two factor analyses were performed.

The Kaiser-Meyer-Olkin (KMO) value for the innovativeness items was 0.674 , and the Barlett's test value was significant. This means that these items were acceptably suitable for factorization. There were five factors extracted, explaining $59.59 \%$ of the total variance. Table 1 shows each factor and its related items.

\section{$<$ Table 1 about here $>$}

The factors shown in Table 1 can be summarized as follows.

Idealism: The extent to which a person tries to reach his/her own goals and has challenges when faced with difficulties as well as how much the person cares about work and issues of dignity and honesty.

Flexibility: How a person perceives and considers different and unconventional approaches to solve problems.

Distinction: How inclined a person is to show or express unexpected and unforeseen ideas.

Systematic approach: To what extent a person is cautious, tidy and favors the use of specific steps to solve problems.

Hunch: How much a person relies on his own hunches to solve problems.

Table 2 shows the Cronbach's alpha values of each innovativeness factor and all respective items. The table reveals that the factors and the innovativeness items are reliable.

$<$ Table 2 about here $>$

The KMO value for the perceived leadership orientation items was 0.685 , and again, the Bartlett's test value was significant. Four leadership orientation factors were extracted; two of these were related to work, while the other two were related to people. The four factors could explain $65.55 \%$ of the total variance. Table 3 shows these factors and their respective items.

\footnotetext{
$<$ Table 3 about here $>$
} 
As shown in Table 3, the four perceived leadership orientation factors are as follows.

Initiative (People Orientation): How much the leader is willing to let workers use initiative in their work.

Over-working (Work Orientation): The extent to which the leader is inclined to demand and/or force workers to work longer and faster.

Conservatism (Work Orientation): How much the leader defends and favors the conventional rules, methods and arrangements in order that workers obey him/her.

Synergy (People Orientation): How much the leader wants to engage with workers and form group synergy by solving intra-group conflicts, acknowledging group success, delegating responsibilities to workers and trusting workers.

Table 4 shows that there are no reliability issues regarding perceived leadership orientation factors and their items.

$<$ Table 4 about here $>$

\subsection{Relationships between owner-manager perceived leadership orientations and innovativeness}

As explained before, many studies claim that leadership inspires some aspects of innovativeness. It is, however, striking that most studies only consider the innovativeness of the workers. In other words, most studies reach the conclusion that leadership is a causal concept for worker innovativeness. The current study acknowledges this conclusion but moves beyond it by focusing exclusively on owner-manager innovativeness. The author of the current study suggests that owner-manager perceived leadership (or at least some leadership orientation aspects) affect innovativeness positively.

In accordance with this assumption, the author analyzed this relationship at three different levels by studying on the effects of owner-manager perceived leadership orientation factors on their innovativeness, the effect of perceived leadership on each factor of their innovativeness and the effect of perceived leadership on their innovativeness. Table 5 shows the results on the effects of owner-manager perceived leadership orientation on innovativeness.

$<$ Table 5 about here $>$

Table 5 makes the following contributions.

The relationship between initiative (people orientation) and innovativeness is statistically significant $(\mathrm{F}=2.540 ; \mathrm{p}<0.05)$. In this case, encouraging initiative under a people orientation affects innovativeness significantly. The portion of the effect is $8.6 \%$ (Ad. $\mathrm{R}^{2}=.086$ ), and the level of the effect is moderate $(\mathrm{R}=0.376)$.

Synergy (people orientation) and innovativeness also show a significant relationship $(F=2.463 ; p<0.05)$. Synergy under a people orientation affects innovativeness significantly by $8.2 \%$ (Ad. $\mathrm{R}^{2}=0.082$ ), and the level of the effect is again moderate $(\mathrm{R}=0.371)$.

The rest of the relationships involving leadership orientation factors and innovativeness are not significant. Over-working under a work orientation does not affect innovativeness significantly $(\mathrm{F}=0.356 ; \mathrm{p}>0.05)$, nor does conservatism under a work orientation $(\mathrm{F}=2.248 ; \mathrm{p}>0.05)$.

While Table 5 shows the effects of owner-managers' perceived leadership orientation factors on their innovativeness, Table 6 shows whether and how perceived leadership affects each factor of their innovativeness.

$<$ Table 6 about here $>$

Table 6 reveals the following findings.

In the significant relationship $(\mathrm{F}=3.532 ; \mathrm{p}<0.05)$ between perceived leadership and distinction, perceived leadership has a positive effect on distinction of $11 \%$ ( $\left.\mathrm{Ad} . \mathrm{R}^{2}=0.110\right)$, and the level of this effect is moderate $(\mathrm{R}=0.392)$.

Similarly, there is a significant relationship $(\mathrm{F}=2.537 ; \mathrm{p}<0.05)$ between perceived leadership and hunch, and perceived leadership affects hunch by $7 \%\left(\right.$ Ad. $\left.\mathrm{R}^{2}=0.070\right)$ at a moderate level $(\mathrm{R}=0.339)$.

There is no significant effect of perceived leadership on the other innovativeness factors.

Finally, Table 7 presents the effect of owner-manager perceived leadership on their innovativeness.

$<$ Table 7 about here $>$

The owner-manager perceived leadership positively and significantly affects innovativeness $(\mathrm{F}=3.418 ; \mathrm{p}<0.05)$ by $12.8 \%$ (Ad. $\left.\mathrm{R}^{2}=0.128\right)$, and the level of the effect is moderate $(\mathrm{R}=0.426)$.

\section{Results and Conclusions}

This study focused on the relationship between leadership orientations and the innovativeness of those who own and manage a business. Though self-reporting was used to measure owner-manager innovativeness, the leadership 
orientations of owner-managers were assessed by their workers. It was expected that the results would be in line with previous findings in the literature; namely, there would be a significant relationship between leadership orientations and innovativeness, and leadership would partially or entirely determine some or all aspects of innovativeness.

Owner-manager innovativeness was composed of five factors, including idealism, flexibility, distinction, systematic approach and hunch. Perceptions regarding their leadership were measured according to two orientations, that is, toward work and toward people. The work orientation implied over-working and conservatism, while the people orientation encouraged initiative and synergy.

The overall results suggest that owner-manager perceived leadership could positively affect the innovativeness of owner-managers at different levels. When perceived leadership orientations were broken down into factors, people-oriented leadership factors affected innovativeness positively and significantly. Put differently, encouraging initiative and synergy causes leaders to be more innovative. This result is in line with the literature, as previous studies also reached the conclusion that innovativeness, social skills and fostering communication were important aspects of leadership.

The results were similar when overall perceived leadership was considered (i.e., with all perceived leadership orientation factors considered together). Owner-manager perceived leadership positively and significantly affected two innovativeness factors (i.e., distinction and hunch). The distinction refers to the capacity to formulate and implement new, unconventional ideas, and as discussed above, this capacity is also addressed in many definitions of innovativeness.

Hunch, the other factor of innovativeness, involves the use of hunches to overcome problems. A similar relationship can be observed between perceived leadership and hunches. Some existing studies have defined innovativeness in terms of cognitive processes or new axes of thoughts, suggesting that the innovativeness process can also facilitate a person's hunches. As such, hunches may be connected with leadership through the innovativeness-leadership relationship.

Finally, owner-manager perceived leadership positively and moderately affected their innovativeness. This final result confirms that there is indeed a connection between leadership and innovativeness, similar to what other studies have found. This finding contributes to the relevant literature on the causal relationships between leadership and innovativeness. The literature contends that the leadership in a work context can inspire innovativeness among individual workers, groups of workers and organizations. In addition to these previous findings in the literature, the results from the present study suggest that perceived leadership can also inspire a leader's own innovativeness.

There is significant research that remains to be done on the relationship between leadership and innovativeness. Future studies might analyze the reverse effects as compared to those analyzed here, namely, whether and how a leader's innovativeness affects a leader's orientation. There may even be mutual relationships between these two factors, which may an interesting aspect for future study. Some studies claim that leadership includes innovativeness, and therefore, future studies might use a systems approach to check whether leader innovativeness is actually a subset of leadership. This study considered two main leadership orientations, namely, toward people and toward work. In the future, more orientations can be considered, or future studies may simultaneously take various different types of leadership into consideration and use a mixed approach to leadership orientations in order to analyze leader innovativeness. Variations in a leader's innovative characteristics according to different types of leadership can also be analyzed. This study used self-reporting for a leader's innovativeness and relied on other people's perceptions of leadership orientations. Alternatively, future analyses can evaluate if there are differences between leadership-innovativeness relationships when self-reporting is exclusively used to measure either innovativeness or leadership as compared to if it is not used at all. In other words, the role of perceptions on the relationship between leadership and innovativeness can be evaluated in greater detail in future studies.

\section{References}

Adair, J. (2007). Leadership for innovation: How to organize team creativity and harvest ideas. Cornwall, UK: MPG Books Limited.

Agarwal, R., \& Prasad, P. (1998). A conceptual and operational definition of personal innovativeness in the domain of information technology. Information Systems Research, 9(2), 204-215, doi:10.1287/isre.9.2.204, http://dx.doi.org/10.1287/isre.9.2.204

Amabile, T. M. (1997). Motivating creativity in organizations: On doing what you love and loving what you do. California Management Review, 40(1), 39-59.

Amabile, T. M. (1998). How to kill creativity. Harvard Business Review, 76(5), 76-87. 
Baer, M., Oldham, G. R., \& Cummings, A. (2003). Rewarding creativity: When does it really matter? The Leadership Quarterly, 14(4-5), 569-586, doi:10.1016/S1048-9843(03)00052-3, http://dx.doi.org/10.1016/S1048-9843(03)00052-3

Baysal, A. C., \& Tekarslan, E. (2004). Davranış Bilimleri [Behavioral sciences] (4th ed.). Istanbul, Turkey: Avciol Publications.

Bennis, W. G. (1989). On becoming a leader. New York, NY: Addison-Wesley Publishing Company.

Burpitt, W. J., \& Bigoness, W. J. (1997). Leadership and innovation among teams: The impact of empowerment. Small Group Research, 28(3), 414-423, doi:10.1177/1046496497283005, http://dx.doi.org/10.1177/1046496497283005

Cengiz, E., Acuner, T., \& Baki, B. (2006). Liderlerin sahip oldukları duygusal zekanın örgütsel yaratıcılık üzerine etkileri: Bir model önerisi [The effects of the leaders' emotional intelligence on organizational creativity: A model proposal]. Ataturk University Journal of Graduate School of Social Sciences, 7(1), 421-433.

Chesbrough, H. (2004). Managing open innovation. Research and Technology Management, 47(1), 23-26.

Choi, D., \& Valikangas, L. (2001). Patterns of strategy innovation. European Management Journal, 19(4), 424-429, doi:10.1016/S0263-2373(01)00045-7, http://dx.doi.org/10.1016/S0263-2373(01)00045-7

Crosby, B. C., \& Bryson, J. M. (2005). A leadership framework for cross-sector collaboration. Public Management Review, 7(2), 177-201, doi:10.1080/14719030500090519, http://dx.doi.org/10.1080/14719030500090519

Daft, R. L. (2008). The leadership experience (4th ed.). Mason, OH: Thomson South-Western.

Deschamps, J. P. (2003). Innovation and leadership. In L. V. Shavinina (Ed.), The international handbook on innovation (pp. 815-831). Oxford, UK: Elsevier Science Ltd, doi:10.1016/B978-008044198-6/50056-5, http://dx.doi.org/10.1016/B978-008044198-6/50056-5

Diakidoy, I. A. N., \& Kanari, E. (1999). Student teacher's beliefs about creativity. British Educational Journal, 25(2), 225-244.

Dudullu Organized Industrial Zone. (2010). Bölgedeki Kuruluşlar [Enterprizes in the zone]. [Online] Available: http://www.idosb.org.tr/bolgedekikuruluslar.asp (October 24, 2010).

Eigen, L. D., \& Siegel, J. P. (1989). The manager's book of quotations. New York, NY: Amacom.

Eisenbeiss, S. A., Knippenberg, D. V., \& Boerner, S. (2008). Transformational leadership and team innovation: Integrating team climate principles. Journal of Applied Psychology, 93(6), 1438-1446, doi:10.1037/a0012716, http://dx.doi.org/10.1037/a0012716

Gibson, J. T., \& Chandler, L. A. (1988). Educational psychology: Mastering principles and applications. Boston, MA: Allyn and Bacon, Inc.

Guilford, J. P. (1961). Creativity. The American Journal of Psychology, 74(4), 663-664, doi:10.2307/1419699, http://dx.doi.org/10.2307/1419699

Gumusluoglu, L. (2009). Inovasyon ve liderlik [Innovation and leadership]. Savunma Sanayi Gündemi Dergisi, 3, $37-42$.

Gumusluoglu, L., \& Ilsev, A. (2009). Transformational leadership, creativity, and organizational innovation. Journal of Business Research, 62(4), 461-473, doi:10.1016/j.jbusres.2007.07.032, http://dx.doi.org/10.1016/j.jbusres.2007.07.032

Guney, S. (2000). Davranış Bilimleri [Behavioral sciences]. (2nd ed.). Ankara, Turkey: Nobel Publications.

Hage, J., \& Dewar, R. (1973). Elite values versus organizational structure in predicting innovation. Administrative Science Quarterly, 18, 279-290, doi:10.2307/2391664, http://dx.doi.org/10.2307/2391664

Herzog, P. (2008). Open and closed innovation: Different cultures for different strategies. Wiesbaden, Germany: GWV Fachverlage $\mathrm{GmbH}$.

Hodgetts, R. M. (1998). Measures of high quality performance. New York, NY: Amacom.

Hunt, J. G., Stelluto, G. E., \& Hooijberg, R. (2004). Toward new-wave organization creativity: Beyond romance and analogy in the relationship between orchestra-conductor leadership and musician creativity. The Leadership Quarterly, 15(1), 145-162, doi:10.1016/j.leaqua.2003.12.009, http://dx.doi.org/10.1016/j.leaqua.2003.12.009

Hurt, H. T., Joseph, K., \& Cook, C. D. (1977). Scales for the measurement of innovativeness. Human Communication Research, 4(1), 58-65, doi:10.1111/j.1468-2958.1977.tb00597.x, http://dx.doi.org/10.1111/j.1468-2958.1977.tb00597.x 
Jung, D. I., Chow, C., \& Wu, A. (2003). The role of transformational leadership in enhancing organizational innovation: Hypotheses and some preliminary findings. The Leadership Quarterly, 14(4-5), 525-544, doi:10.1016/S1048-9843(03)00050-X, http://dx.doi.org/10.1016/S1048-9843(03)00050-X

Kiesswetter, K. (1983). Modellierung von Problemloeseprozessen [Modelling for problem solving processes], Mathematikunterricht, 29(3), 71-101.

Klemm, W. R. (2001). Leadership: Creativity and innovation. In R. I. Lester \& A. G. Morton (Eds.), Concepts for air force leadership (pp. 449-462). Montgomery, AL: Air University Press.

Kocel, T. (2003). İşletme Yöneticiliği [Business management]. (9th ed.). Istanbul, Turkey: Beta Publications.

Krause, D. E., Gebert, D., \& Kearney, E. (2007). Implementing process innovations: The benefits of combining delegative-participative with consultative-advisory leadership. Journal of Leadership \& Organizational Studies, 14(1), 16-25, doi:10.1177/1071791907304224, http://dx.doi.org/10.1177/1071791907304224

Luthans, F. (1995). Organizational behavior. (7th ed.). New York, NY: McGraw-Hill Inc.

Maier, N. R. F. (1970). Problem solving and creativity in individuals and in groups. Belmont, CA: Brooks/Cole.

Mogulkoc, K. G. (2009). Yönetici hemşirelerin yaratıcılık düzeyleri ve liderlik tarzlarının belirlenmesi [The determination of creativity levels and leadership styles of executive nurses]. (Master's thesis, Halic University, Turkey). [Online] Available: http://tez2.yok.gov.tr/ (December 18, 2010).

Mumford, M. D., \& Gustafson, S. B. (1988). Creativity syndrome: Integration, application and innovation. Psychological Bulletin, 103(1), 27-43, doi:10.1037//0033-2909.103.1.27, http://dx.doi.org/10.1037//0033-2909.103.1.27

Raudsepp, E., \& Hough, G. P. (1977). Creative growth games. New York, NY: Jave Publications.

Riza, E. T. (2000). Çocuklarda ve yetişkinlerde yaratıcılık nasıl uyarılır? [How to stimulate the creativity of children and adults?]. Yaşadıkça Eğitim Dergisi, 68, 5-12.

Rowitz, L. (2001). Public health leadership: Putting principles into practice. Gaithersburg, MD: Aspen Publishers Inc.

Torrance, E. P., \& Wu, T. (1981). A comparative longitudinal study of the adult creative achievements of elementary school children identified as highly intelligent and as highly creative. Creative Child and Adult Quarterly, 6, 71-76.

Vecchio, R. P. (1988). Organizational behavior. (2nd ed.). Chicago: The Dryden Press.

Wakefield, J. F. (1992). Creative thinking: Problem solving skill and the arts orientation. Norwood, NJ: Ablex Publishing Corporation.

Yavuzer, H. (1994). Yaratıcllk [Innovativeness]. (2nd ed.). Istanbul, Turkey: Bogazici University Publications.

Yukl, G. A. (2001). Leadership in organizations. (5th ed.). Upper Saddle River, NJ: Prentice Hall.

Zel, U. (2001). Kişilik ve Liderlik [Personality and leadership]. Ankara, Turkey: Seckin Publications.

Zhou, J., \& George, J. M. (2003). Awakening employee creativity: The role of leader emotional intelligence. The

Leadership Quarterly, 14(4-5), 545-568, doi:10.1016/S1048-9843(03)00051-1,

http://dx.doi.org/10.1016/S1048-9843(03)00051-1 
Table 1. The results of explanatory factor analysis on owner-manager innovativeness

\begin{tabular}{|c|c|c|c|c|c|}
\hline \multicolumn{6}{|c|}{ Rotated Component Matrix ${ }^{a}$} \\
\hline & Idealism & Flexibility & Distinction & $\begin{array}{l}\text { Systematic } \\
\text { approach }\end{array}$ & Hunch \\
\hline $\begin{array}{l}\text { It is more important for me to act in the fair way than to have } \\
\text { other people's approval. }\end{array}$ & 0.836 & & & & \\
\hline $\begin{array}{l}\text { I lose my respect for people who cannot act consistently when } \\
\text { facing different situations. }\end{array}$ & 0.807 & & & & \\
\hline I can go on searching for solutions to very difficult problems. & 0.774 & & & & \\
\hline $\begin{array}{l}\text { I like people who act according to the rule of "work before } \\
\text { fun." }\end{array}$ & 0.758 & & & & \\
\hline $\begin{array}{l}\text { Self-respect is more important than the respect other people } \\
\text { show. }\end{array}$ & 0.744 & & & & \\
\hline $\begin{array}{l}\text { I can easily abandon benefits or comforts in order to reach my } \\
\text { goals. }\end{array}$ & 0.724 & & & & \\
\hline I believe that the road to success is through hard work. & 0.709 & & & & \\
\hline $\begin{array}{l}\text { The best ideas generally come into my mind when I am not } \\
\text { busy. }\end{array}$ & & 0.809 & & & \\
\hline I think that the people who chase perfection are not very wise. & & 0.774 & & & \\
\hline $\begin{array}{l}\text { I can easily change my method when I understand that a } \\
\text { specific approach to a problem does not provide any benefit. }\end{array}$ & & 0.738 & & & \\
\hline I like to ask questions that have no answers. & & 0.734 & & & \\
\hline $\begin{array}{l}\text { The inability to solve a problem is sometimes the result of } \\
\text { asking the wrong questions. }\end{array}$ & & 0.687 & & & \\
\hline I can sometimes find quick solutions to problems. & & 0.636 & & & \\
\hline $\begin{array}{l}\text { The problems of many people arise from their extreme } \\
\text { seriousness toward events and matters. }\end{array}$ & & 0.608 & & & \\
\hline $\begin{array}{l}\text { I sometimes formulate ideas that are unconventional enough to } \\
\text { surprise people in social situations. }\end{array}$ & & & 0.831 & & \\
\hline I believe that I can make a difference to humanity. & & & 0.764 & & \\
\hline $\begin{array}{l}\text { Diving into my world of dreams causes my mind to generate } \\
\text { many important thoughts and projects. }\end{array}$ & & & 0.744 & & \\
\hline $\begin{array}{l}\text { I prefer to discover new ideas rather than getting my ideas } \\
\text { approved by other people. }\end{array}$ & & & 0.689 & & \\
\hline I like to astonish other people. & & & 0.641 & & \\
\hline $\begin{array}{l}\text { I like to be full of new ideas, even if they do not provide me } \\
\text { with any solutions. }\end{array}$ & & & 0.593 & & \\
\hline $\begin{array}{l}\text { I believe that the best method to solve problems is to move } \\
\text { step by step, logically. }\end{array}$ & & & & 0.851 & \\
\hline $\begin{array}{l}\text { I work slowly and carefully when I synthesize information that } \\
\text { I get very quickly and that is related to the problem at hand. }\end{array}$ & & & & 0.833 & \\
\hline $\begin{array}{l}\text { I mostly want to make sure that I always follow the right steps } \\
\text { when solving a specific problem. }\end{array}$ & & & & 0.811 & \\
\hline $\begin{array}{l}\text { It is important to me that everything has a place and } \\
\text { everything is in its place. }\end{array}$ & & & & 0.667 & \\
\hline $\begin{array}{l}\text { It is acceptable to ask questions that may not have any specific } \\
\text { and concrete answers. }\end{array}$ & & & & & 0.767 \\
\hline $\begin{array}{l}\text { When I approach the solution of a problem, I trust my hunches } \\
\text { and my instincts about what is right or wrong. }\end{array}$ & & & & & 0.740 \\
\hline Hunches are reliable guides to solving problems. & & & & & 0.679 \\
\hline $\begin{array}{l}\text { I frequently start work on a problem that I do not fully } \\
\text { understand and cannot yet explain. }\end{array}$ & & & & & 0.672 \\
\hline
\end{tabular}


Extraction Method: Principal Component Analysis.

Rotation Method: Varimax with Kaiser Normalization.

a. Rotation converged in five iterations.

Table 2 . The results of the reliability analyses on the owner-manager innovativeness items

\begin{tabular}{|c|c|}
\hline Factors & Cronbach's alpha values \\
\hline Idealism & 0.885 \\
\hline Flexibility & 0.850 \\
\hline Distinction & 0.809 \\
\hline Systematic approach & 0.825 \\
\hline Hunch & 0.717 \\
\hline All items & 0.726 \\
\hline
\end{tabular}

Table 3. The results of the explanatory factor analysis on perceived leadership orientation items

\begin{tabular}{|c|c|c|c|c|}
\hline \multicolumn{5}{|c|}{ Rotated Component Matrix ${ }^{a}$} \\
\hline & $\begin{array}{c}\text { Initiative } \\
\text { (People } \\
\text { Orientation) }\end{array}$ & $\begin{array}{l}\text { Over-working } \\
\text { (Work } \\
\text { Orientation) } \\
\end{array}$ & $\begin{array}{l}\text { Conservatism } \\
\text { (Work } \\
\text { Orientation) }\end{array}$ & $\begin{array}{c}\text { Synergy } \\
\text { (People } \\
\text { Orientation) } \\
\end{array}$ \\
\hline $\begin{array}{l}\text { The owner-manager of the business lets us decide } \\
\text { on our own about work issues. }\end{array}$ & 0.928 & & & \\
\hline $\begin{array}{l}\text { The owner-manager of the business allows us to use } \\
\text { our own methods while solving certain problems. }\end{array}$ & 0.908 & & & \\
\hline $\begin{array}{l}\text { The owner-manager of the business provides us } \\
\text { with freedom up to a certain point. }\end{array}$ & 0.883 & & & \\
\hline $\begin{array}{l}\text { We can act as we wish in certain business } \\
\text { emergencies. }\end{array}$ & 0.879 & & & \\
\hline $\begin{array}{l}\text { The owner-manager of the business usually } \\
\text { supports our ideas about the business. }\end{array}$ & 0.737 & & & \\
\hline $\begin{array}{l}\text { The owner-manager of the business feels } \\
\text { comfortable passing along some of his/her authority } \\
\text { to certain subordinates. }\end{array}$ & 0.653 & & & \\
\hline $\begin{array}{l}\text { The owner-manager of the business has a tolerance } \\
\text { for ambiguities and delays in our work. }\end{array}$ & 0.613 & & & \\
\hline $\begin{array}{l}\text { The owner-manager of the business lets us decide } \\
\text { how fast we work. }\end{array}$ & 0.591 & & & \\
\hline $\begin{array}{l}\text { The owner-manager of the business generally } \\
\text { prefers to act after he/she consults certain } \\
\text { subordinates. }\end{array}$ & 0.587 & & & \\
\hline $\begin{array}{l}\text { The owner-manager of the business wants us to } \\
\text { work more. }\end{array}$ & & 0.892 & & \\
\hline $\begin{array}{l}\text { The owner-manager of the business wants us to } \\
\text { work more enthusiastically. }\end{array}$ & & 0.840 & & \\
\hline $\begin{array}{l}\text { The owner-manager of the business wants us to } \\
\text { work faster. }\end{array}$ & & 0.792 & & \\
\hline $\begin{array}{l}\text { The owner-manager of the business encourages us } \\
\text { to be more productive by offering rewards. }\end{array}$ & & 0.730 & & \\
\hline $\begin{array}{l}\text { The owner-manager of the business encourages us } \\
\text { to work over-time. }\end{array}$ & & 0.537 & & \\
\hline $\begin{array}{l}\text { The owner-manager of the business encourages the } \\
\text { use of specific methods in the business. }\end{array}$ & & & 0.926 & \\
\hline The owner-manager of the business personally & & & 0.855 & \\
\hline
\end{tabular}




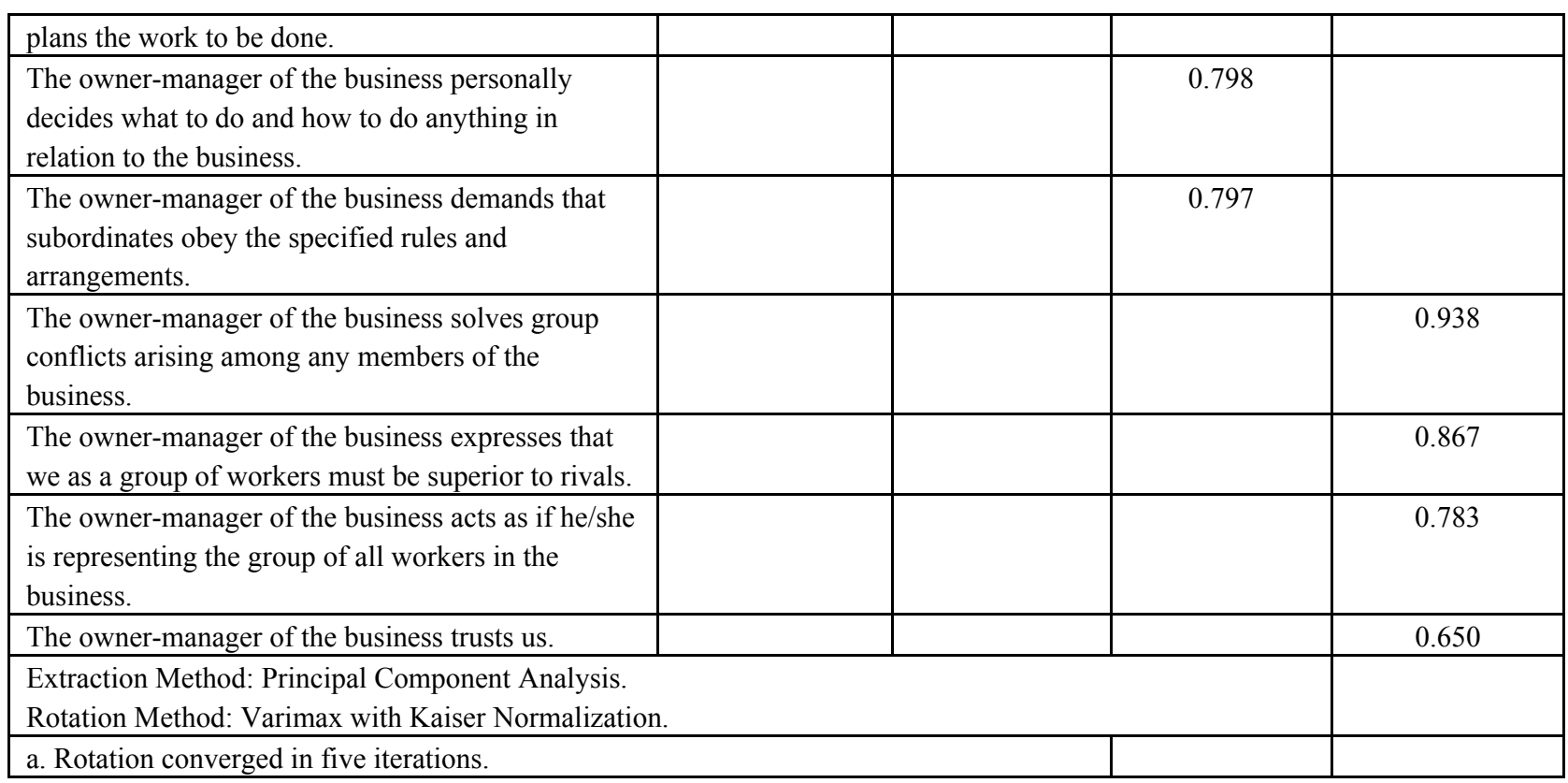

Table 4. The results of the reliability analyses on perceived leadership orientation items

\begin{tabular}{|l|c|}
\hline \multicolumn{1}{|c|}{ Factors } & Cronbach's alpha values \\
\hline Initiative (People Orientation) & 0.906 \\
\hline Over-working (Work Orientation) & 0.818 \\
\hline Conservatism (Work Orientation) & 0.871 \\
\hline Synergy (People Orientation) & 0.837 \\
\hline All of the items & 0.798 \\
\hline
\end{tabular}

Table 5. The results on the effects of owner-manager perceived leadership orientation factors on innovativeness

\begin{tabular}{|c|c|c|c|c|c|c|}
\hline \multicolumn{7}{|c|}{ Initiative (People Orientation) and Innovativeness } \\
\hline \multicolumn{4}{|c|}{ ANOVA } & \multicolumn{3}{|c|}{ Model Summary } \\
\hline & df & $\mathbf{F}$ & $\mathbf{P}$ & $\mathbf{R}$ & $\mathbf{R}^{2}$ & Ad. $\mathbf{R}^{2}$ \\
\hline Regression & $5-77$ & 2.540 & 0.035 & 0.376 & 0.142 & 0.086 \\
\hline \multicolumn{7}{|c|}{ Synergy (People Orientation) and Innovativeness } \\
\hline \multicolumn{4}{|c|}{ ANOVA } & \multicolumn{3}{|c|}{ Model Summary } \\
\hline & df & $\mathbf{F}$ & $\mathbf{P}$ & $\mathbf{R}$ & $\mathbf{R}^{2}$ & Ad. $\mathbf{R}^{2}$ \\
\hline Regression & $5-77$ & 2.463 & 0.040 & 0.371 & 0.138 & 0.082 \\
\hline \multicolumn{7}{|c|}{ Over-working (Work Orientation) and Innovativeness } \\
\hline \multicolumn{4}{|c|}{ ANOVA } & \multicolumn{3}{|c|}{ Model Summary } \\
\hline & df & $\mathbf{F}$ & $\mathbf{P}$ & $\mathbf{R}$ & $\mathbf{R}^{2}$ & Ad. $\mathbf{R}^{2}$ \\
\hline Regression & $5-77$ & 0.356 & 0.877 & 0.150 & 0.023 & -0.041 \\
\hline \multicolumn{7}{|c|}{ Conservatism (Work Orientation) and Innovativeness } \\
\hline \multicolumn{4}{|c|}{ ANOVA } & \multicolumn{3}{|c|}{ Model Summary } \\
\hline & df & $\mathbf{F}$ & $\mathbf{P}$ & $\mathbf{R}$ & $\overline{\mathbf{R}^{2}}$ & Ad. $R^{2}$ \\
\hline Regression & $5-77$ & 2.248 & 0.058 & 0.357 & 0.127 & 0.071 \\
\hline
\end{tabular}


Table 6. The results on the effects of owner-manager perceived leadership on innovativeness factors

\begin{tabular}{|c|c|c|c|c|c|c|}
\hline \multicolumn{7}{|c|}{ Perceived Leadership and Distinction } \\
\hline \multicolumn{4}{|c|}{ ANOVA } & \multicolumn{3}{|c|}{ Model Summary } \\
\hline & df & $\mathbf{F}$ & $\mathbf{P}$ & $\mathbf{R}$ & $\mathbf{R}^{2}$ & Ad. $\mathbf{R}^{2}$ \\
\hline Regression & $4-78$ & 3.532 & 0.011 & 0.392 & 0.153 & 0.110 \\
\hline \multicolumn{7}{|c|}{ Perceived Leadership and Hunch } \\
\hline \multicolumn{4}{|c|}{ ANOVA } & \multicolumn{3}{|c|}{ Model Summary } \\
\hline & df & $\mathbf{F}$ & $\mathbf{P}$ & $\mathbf{R}$ & $\mathbf{R}^{2}$ & Ad. $\mathbf{R}^{2}$ \\
\hline Regression & $4-78$ & 2.537 & 0.047 & 0.339 & 0.115 & 0.070 \\
\hline \multicolumn{7}{|c|}{ Perceived Leadership and Idealism } \\
\hline \multicolumn{4}{|c|}{ ANOVA } & \multicolumn{3}{|c|}{ Model Summary } \\
\hline & df & $\mathbf{F}$ & $\mathbf{P}$ & $\mathbf{R}$ & $\mathbf{R}^{\mathbf{2}}$ & Ad. $\mathbf{R}^{2}$ \\
\hline Regression & $4-78$ & 0.746 & 0.564 & 0.192 & 0.037 & -0.013 \\
\hline \multicolumn{7}{|c|}{ Perceived Leadership and Flexibility } \\
\hline \multicolumn{4}{|c|}{ ANOVA } & \multicolumn{3}{|c|}{ Model Summary } \\
\hline & df & $\mathbf{F}$ & $\mathbf{P}$ & $\mathbf{R}$ & $\mathbf{R}^{2}$ & Ad. $\mathbf{R}^{2}$ \\
\hline Regression & $4-78$ & 1.320 & 0.270 & 0.252 & 0.063 & 0.015 \\
\hline \multicolumn{7}{|c|}{ Perceived Leadership and Systematic Approach } \\
\hline \multicolumn{4}{|c|}{ ANOVA } & \multicolumn{3}{|c|}{ Model Summary } \\
\hline & df & $\mathbf{F}$ & $\mathbf{P}$ & $\mathbf{R}$ & $\mathbf{R}^{2}$ & Ad. $\mathbf{R}^{2}$ \\
\hline Regression & $4-78$ & 1.968 & 0.108 & 0.303 & 0.092 & 0.045 \\
\hline
\end{tabular}

Table 7. The results on the effects of owner-manager perceived leadership on innovativeness

\begin{tabular}{|c|c|c|c|c|c|c|}
\hline \multicolumn{7}{|c|}{ Perceived Leadership and Innovativeness } \\
\hline & df & F & P & R & $\mathbf{R}^{\mathbf{2}}$ & $\begin{array}{c}\text { Ad. } \\
\mathbf{R}^{\mathbf{2}}\end{array}$ \\
\hline Regression & $5-77$ & 3.418 & 0.008 & 0.426 & 0.182 & 0.128 \\
\hline
\end{tabular}

